\title{
Chrysoberyl-sillimanite association from the Roncadeira pegmatite, Borborema Province, Brazil: implications for gemstone exploration
}

\author{
Hartmut BEURLEN ${ }^{*}$, Rainer THOMAS², Joan Carles MELGAREJO ${ }^{3}$, José Maurício R. Da SILVA', \\ Dieter RHEDE², Dwight R. SOARES ${ }^{4}$, Marcelo R. R. DA SILVA'
}

${ }^{1}$ Departamento de Geologia, Universidade Federal de Pernambuco (UFPE), Rua Acadêmico Hélio Ramos s.n., 50740-530, Recife, Pernambuco,Brazil; beurlen@ufpe.br

${ }^{2}$ Helmholtz-Centre Potsdam, German Research Centre for Geoscience (GFZ), Telegrafenberg, D-14473 Potsdam, Germany

${ }^{3}$ Department de Cristallografia, Mineralogia i Dipòsits Minerals, Universitat de Barcelona, E-08013 Barcelona, Spain

${ }^{4}$ Instituto Federal de Educação, Ciência e Tecnologia da Paraíba (IFPB), R. Tranquilino Coelho Lemos 671, 58100-000, Campina Grande-Paraiba, Brazil

* Corresponding author

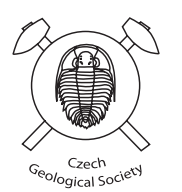

The first occurrence of chrysoberyl in the Borborema Pegmatite Province (BPP) in northeastern Brazil is reported from up to $0.5 \mathrm{~m}$ large boulders in the dumps covering the Roncadeira pegmatite, worked in the 1940's for Sn- and Ta-ore concentrate. The chrysoberyl occurs in tabular, transparent light yellow crystals, up to two centimeters across. It is associated with quartz and fibrolitic sillimanite along centimeter-thick sigmoidal shear zones crosscutting banded sodic aplite facies of the pegmatite. Along the crystal borders, the chrysoberyl (Cbl) contains commonly small rounded inclusions of quartz and microscopic fibrous radial aggregates of sillimanite. A metamorphic-metasomatic origin of the chrysoberyl by the reaction Beryl + albite + muscovite $+\mathrm{H}^{+}=$chrysoberyl + quartz + sillimanite $+\mathrm{Na}+\mathrm{K}+\mathrm{H}_{2} \mathrm{O}$, seems to be the most plausible to explain the observed textural relations.

Chrysoberyl contains 1.25 to 1.81 wt. \% FeO ${ }^{\text {tot }}$. Contents of $\mathrm{SiO}_{2}$ and other, potentially chromophore oxides of $\mathrm{Cr}, \mathrm{V}$, and $\mathrm{Ti}$ are mostly below limits of detection. A few exceptions for $\mathrm{Si}$ and $\mathrm{V}$ are below $0.01 \mathrm{wt}$ \% oxide. The average formula along an electron-microprobe scan from core to rim of a selected $\mathrm{Cbl}$ crystal is: $\mathrm{Be}_{0.931 \pm 0.017}\left(\mathrm{Al}_{2.028 \pm 0.011}, \mathrm{Fe}_{0.026 \pm 0.002}\right)_{\Sigma 2.054 \pm 0.013} \mathrm{O}_{4}$ $( \pm 1 \sigma, \mathrm{n}=92)$.

The origin of sillimanite + chrysoberyl + quartz under amphibolite-grade metamorphic conditions $\left(\sim 600^{\circ} \mathrm{C}, 3.5\right.$ to $5 \mathrm{kbar}$ ) implies either an existence of a new generation of syn-metamorphic REL-pegmatites in the BPP or a late-tectonic recurrent increase in $\mathrm{P}-\mathrm{T}$ conditions in the area. Another, less probable, alternative is a metastable formation of chrysoberyl and sillimanite at lower, retrometamorphic P-T conditions.

The interaction of similar pegmatites known to occur south and north of Roncadeira with metabasic rock intercalations in the Seridó Formation opens the perspective for the finding of the gem-variety alexandrite in the BPP.

Keywords: chrysoberyl, metamorphosed REL-pegmatite, Seridó Belt, Borborema Province, Brazil

Received: 8 February 2013; accepted: 18 June 2013; handling editor: R. Škoda

The online version of this article (doi: 10.3190/jgeosci.142) contains supplementary electronic material.

\section{Introduction}

The most common primary magmatic beryllium minerals in pegmatites are the silicates beryl and, rarely, phenakite, along with rare phosphates (hurlbutite or herderite) or borates (hambergite). There are only a few of natural beryllium minerals belonging to the oxide class: bromellite $[\mathrm{BeO}]$, behoite $\left[\mathrm{Be}(\mathrm{OH})_{2}\right]$ chrysoberyl $\left[\mathrm{Al}_{2} \mathrm{BeO}_{4}\right]$ and the taaffeite group minerals with magnesiotaaffeite- $2 \mathrm{~N}^{\prime} 2 \mathrm{~S}\left[\mathrm{Mg}_{3} \mathrm{Al}_{8} \mathrm{BeO}_{16}\right]$, magnesiotaaffeite-6N'3S $\left[\left(\mathrm{Mg}, \mathrm{Fe}^{2+}, \mathrm{Zn}\right)_{2} \mathrm{Al}_{6} \mathrm{BeO}_{12}\right]$ and ferrotaaffeite- $6 \mathrm{~N}^{\prime} 3 \mathrm{~S}\left[\left(\mathrm{Fe}^{2+}, \mathrm{Zn}, \mathrm{Mg}\right)_{2} \mathrm{Al}_{6} \mathrm{BeO}_{12}\right]$.

Bromellite is very rare in granite pegmatites; it is more common in alkaline ones. Thomas and Davidson (2010) showed that $\mathrm{BeO}$ is highly mobile in waterbearing systems at temperatures higher than $600{ }^{\circ} \mathrm{C}$.
Chrysoberyl is often related to a local enrichment of the mineral-forming melts or solutions in aluminum, for example by assimilation of the host rocks (Beus 1966). The taaffeite-group minerals in granitic pegmatites are only known as products of metamorphism (Černý 2002).

The chrysoberyl $(\mathrm{Cbl})$ in the Roncadeira pegmatite, $4 \mathrm{~km}$ WNW from the Nova Palmeira township in the Borborema Pegmatite Province (BPP), State of Paraiba, northeastern Brazil, (see Fig. 1 for localization) was first macroscopically recognized by the third author (JCM) during a field trip in 2005 together with the first and last authors. After its confirmation by powder XRD it was mentioned by Beurlen et al. (2008) without any mineralogical details. In the present study, electron microprobe analyses, Raman spectroscopy and petrogenetic 


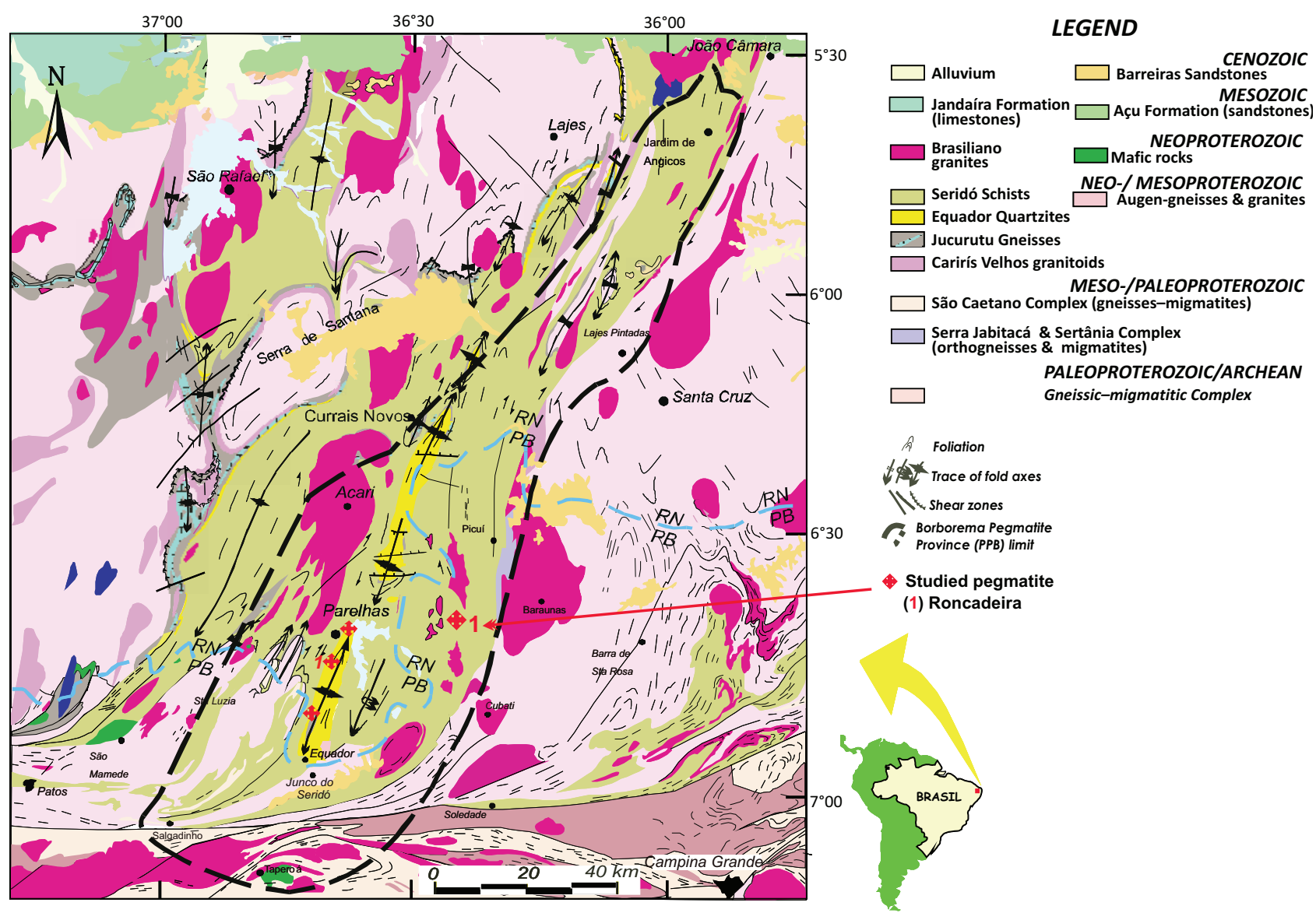

Fig. 1 Regional geological sketch of the Borborema Pegmatite Province and the Roncadeira pegmatite.

considerations based on textural relations are presented. Besides implications on the local pegmatite-forming processes, the recognition of the presence of chrysoberyl in the BPP may be important because it opens the possibility for the presence of gem-quality varieties (alexandrite or cat's eye) in areas which formed under similar tectonic regime.

\section{Geological setting}

The Roncadeira pegmatite was first described by Roy et al. (1964) as a string of cassiterite-, columbite- and beryl-bearing pegmatite lenses usually less than two meters thick; they are enclosed in sillimanite-garnetcordierite-biotite schists and gneisses (from now on biotite schists, for simplicity) of the Neoproterozoic Seridó Formation (Seridó Foldbelt, Northern Domain of the Borborema Tectonic Province; Van Schmus et al. 2003). The Serido Formation is the uppermost unit overlying the Equador (quartzites and metaconglomerates) and Jucurutú (gneisses) formations of the Seridó Group. The rock sequence was metamorphosed with the peak metamorphic conditions reaching amphibolite grade $\left(\sim 600^{\circ} \mathrm{C}, 3.5\right.$ to $\left.5 \mathrm{kbar}\right)$ at $c .590 \mathrm{Ma}$. The rareelement class (REL-class, according to the pegmatite classification of Černý and Ercit 2005) Be-Li-Ta-Sn mineralized pegmatites were emplaced between 500 and $520 \mathrm{Ma}$ supposedly under regional greenschist-facies metamorphism during, or related to, the ductile-brittle reactivation of older NNE-oriented strike-slip shear zones and related tension gashes or extension fractures (Araújo et al. 2005 and references therein). Temperature conditions of this retrograde greenschist-facies metamorphic overprint were estimated between 275 and $400^{\circ} \mathrm{C}$, based on the transformation of the peak metamorphic paragenesis into chlorite + muscovite + biotite schists in the shear zones and also regionally along the axial cleavage related to open normal folds (for details, see Araújo et al. 2005 and references therein). Timing of this event was based on biotite Ar-Ar geochronology (Araújo et al. 2005) and columbite U-Pb data (Baumgartner et al. 2006).

The group of pegmatite lenses at Roncadeira strikes NNE, parallel or sub-parallel to the foliation of the enclosing biotite schists, and has a subvertical dip toward ESE, crosscutting the more gently dipping foliation of the host rocks. According to the pegmatite classifica- 


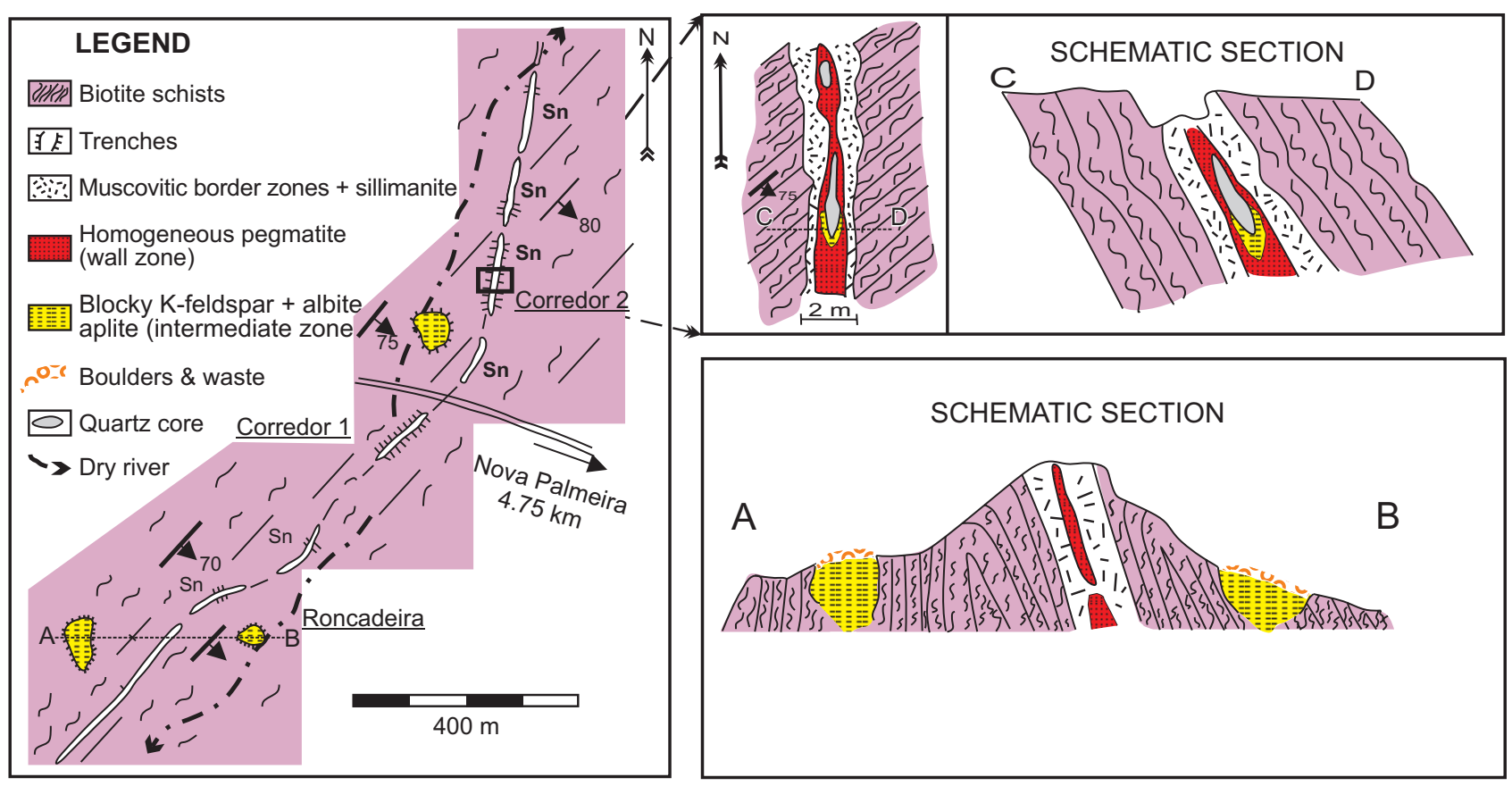

Fig. 2 Local geological sketch of the Roncadeira-Corredor pegmatite group.

tion of Černý and Ercit (2005), the Roncadeira pegmatites belong to the beryl type of the rare-element class (Beurlen et al. 2008). Da Silva (1993) recognized the presence of wodginite in addition to the other dominant minerals of economic interest (cassiterite, beryl and columbite-tantalite group minerals) earlier registered by Rolff (1946) and Roy et al. (1964). Beurlen et al. $(2007,2008)$ reported ferrowodginite, tapiolite-(Fe), "strüverite", titanian ixiolite, chrysoberyl and gahnite as additional accessory ore minerals, in a study on the relationship between composition of the columbite-group minerals and the degree of fractionation of the pegmatites in the BPP. Other frequent accessory phases in the pegmatites are spessartine and zircon, and a few up to $0.3 \mathrm{~mm}$ sized grains of a $\mathrm{Zn}-\mathrm{Sn}-\mathrm{Al}$-bearing mineral tentatively identified as "zinconigerite-6N6S". The latter is a $\mathrm{Zn}$-dominant polytype still not approved by IMA, unlike the well-known ferronigerite-6N6S (with Fe $>$ Zn) of the nigerite group.

The Roncadeira pegmatite lenses are usually almost homogeneous or weakly zoned (Fig. 2). They mostly display a muscovite-enriched border zone up to $10 \mathrm{~cm}$ thick - described as "greisen" by Roy et al. (1964). It is followed inward by the homogeneous pegmatite (or wall zone), which consists of a medium-grained aggregate of quartz $+\mathrm{K}$-feldspar + muscovite \pm albite; only locally it is possible to observe a discontinuous intermediate zone dominated by blocky K-feldspar and the intermittent quartz core. Even less frequent are small lenticular subconcordant pockets of banded aplite formed by a fine-grained saccharoidal albite and variable proportions of quartz and muscovite. Cassiterite and ferrowodginite form millimeter- or up to centimeter-sized disseminated grains, which are enriched in the muscovite-rich border zone and less common in the wall zone. In addition to muscovite, quartz and feldspar, sillimanite is observed as a widespread accessory mineral in the border zone. It forms either nodular fibro-radial aggregates clearly related to thin shear zones or grew at expense of muscovite by partial peripheral replacement of the latter and also bordering augen-shaped K-feldspar and albite grains. The sillimanite occurs as a major component (up to 20 vol. \%) in a few larger shear zones up to $c .10 \mathrm{~cm}$ wide crosscutting the pegmatite.

The quartz of the banded sodic aplite often contains metamict grains of zircon. These sometimes have an ideal spherical shape (see Electronic Appendix - Fig. S1) and could therefore be important hints for the sedimentary source origin of the granite parental to the pegmatites. Geochronological analyses are necessary to check this possibility.

Chrysoberyl (Cbl) was found only in a few decimetersized boulders of banded albite-dominated saccharoidal aplite (+quartz + muscovite) in the dumps of one lens at Roncadeira (see Fig. 2 for location), and in another small aplite block found in the dumps of the Corredor pegmatite, north of Roncadeira. In most samples, Cbl-crystals were clearly related and restricted to lenticular quartz + sillimanite aggregates in the shear zones crosscutting the banded albitic aplites (Fig. 3). Chrysoberyl occurs as tabular transparent very pale yellowish-green crystals up to $15 \mathrm{~mm}$ long and $4 \mathrm{~mm}$ thick, which can sometimes 


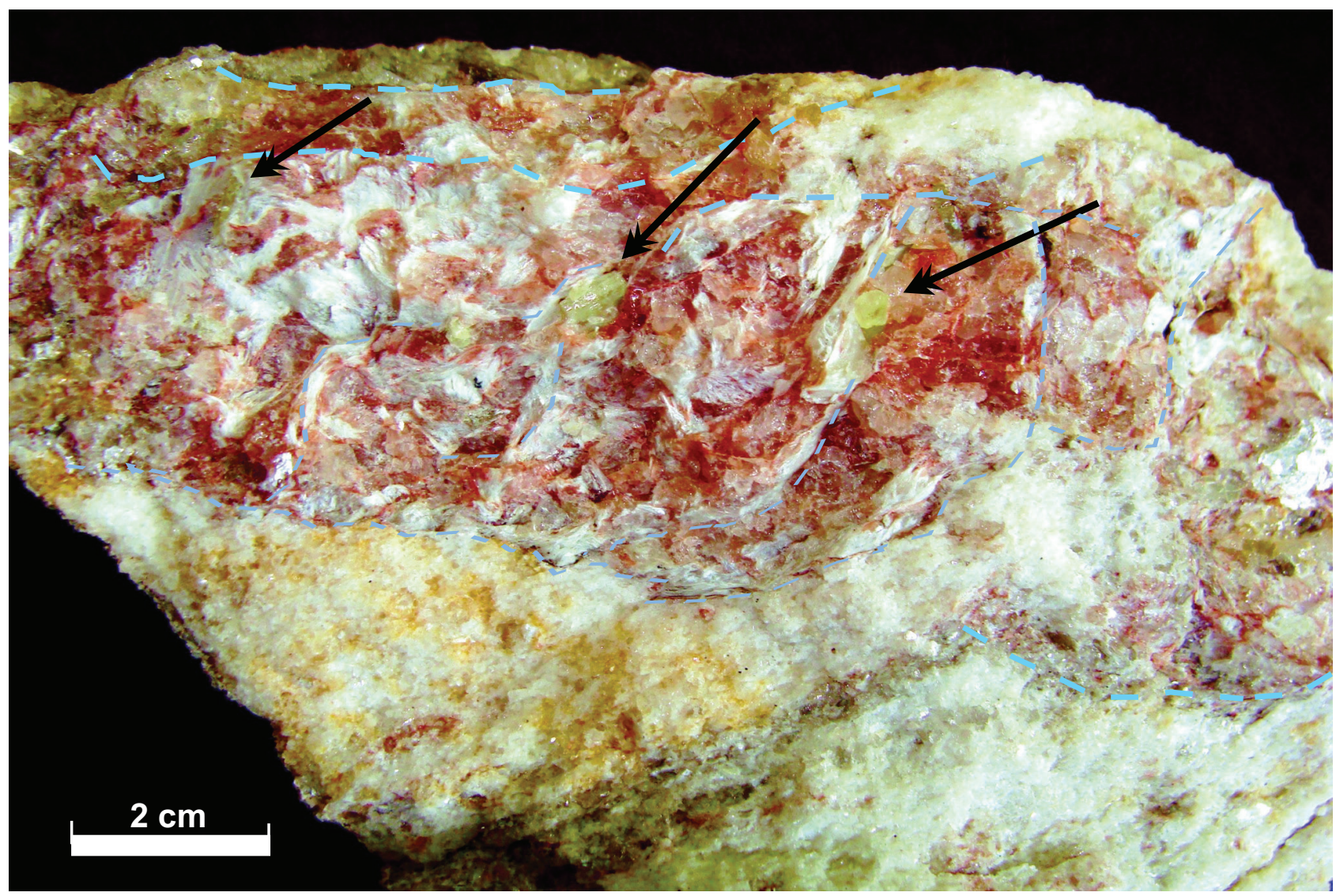

Fig. 3 Photograph of the chrysoberyl assemblage in a sample of the white to yellowish gray banded sodic aplite (saccharoidal albite with minor quartz and muscovite) (bottom), crosscut by an orange-red quartz-dominated shear zone $\sim 2.5 \mathrm{~cm}$ thick (top). Several secondary sigmoidal shear surfaces ( $\mathrm{S}$ and $\mathrm{C}$, respectively; marked by the blue dashed lines) stand out due to the content of white fibrolitic sillimanite. Black arrows mark some pale yellowish-green chrysoberyl crystals. The reddish color of quartz in the shear zone is due to iron hydroxide impregnation along microfractures.

be distinguished by the typical pseudo-hexagonal cyclic penetration twinning. The crystals are colorless in thin sections, without pleochroism and no visible alexandrite effect. Weak pleochroism was seen only in sections more than $0.2 \mathrm{~mm}$ thick prepared for fluid-inclusion studies and electron-microprobe analysis. Both Qtz and $\mathrm{Cbl}$ in the shear zones are rich in sillimanite inclusions with acicular habit or forming fibro-radial bundles (Fig. 4a-d) indicating a porphyroblastic growth of quartz and chrysoberyl, syngenetic with, or post-dating, the sillimanite.

The macroscopic identification of the chrysoberyl was confirmed, along with microprobe data, using powder XRD and Raman spectrometry (see Electronic Appendix - Figs S3-S4).

The albite-rich portions of the banded aplite contain submillimeter-sized accessory tapiolite-(Fe), ferrowodginite and columbite-( $\mathrm{Fe})$, all of which are also found in the border and wall zones of the pegmatite. In addition occur some spessartine, gahnite and rare grains of the $\mathrm{Zn}$-dominated polytype of the nigerite group, mentioned above.

\section{Chrysoberyl chemistry}

\subsection{Analytical techniques}

Electron-microprobe (EMP) analyses were performed with the JEOL JXA-8500F (Hyperprobe) at the Helmholtz Centre Potsdam, German Research Centre for Geoscience (GFZ). First, EDS mode analyses allowed to establish that the main components present were $\mathrm{Be}$, $\mathrm{Al}, \mathrm{V}, \mathrm{Si}, \mathrm{Ti}, \mathrm{Cr}$ and $\mathrm{Fe}$. Using the WDS mode, thirteen preliminary quantitative EMP analyses showed that $\mathrm{V}, \mathrm{Cr}$ and Ti remained below the limits of detection. Operating conditions for quantitative WDS analyses involved an accelerating voltage of $10 \mathrm{kV}$, a beam current of 300 $\mathrm{nA}$ and a beam diameter of $5 \mu \mathrm{m}$. The counting times on the peaks were $300 \mathrm{~s}$ for $\mathrm{Be}\left(\mathrm{K}_{\alpha}\right)$ (LDEB), $40 \mathrm{~s}$ for $\mathrm{Al} \mathrm{K}_{\beta}$ (TAP), $\mathrm{Fe}\left(\mathrm{K}_{\alpha}\right)(\mathrm{LiF})$ and $\mathrm{Si}\left(\mathrm{K}_{\alpha}\right)(\mathrm{PETH})$. In each case, the background was counted for halftime on both sides of the peak. Corundum ( $\mathrm{Al})$, jadeite $(\mathrm{Si})$, hematite $(\mathrm{Fe})$ and euclase $(\mathrm{Be})$ were used as calibration standards. The matrix corrections were employed according to the CITZAF method (Armstrong 1995). Quantitative preliminary 

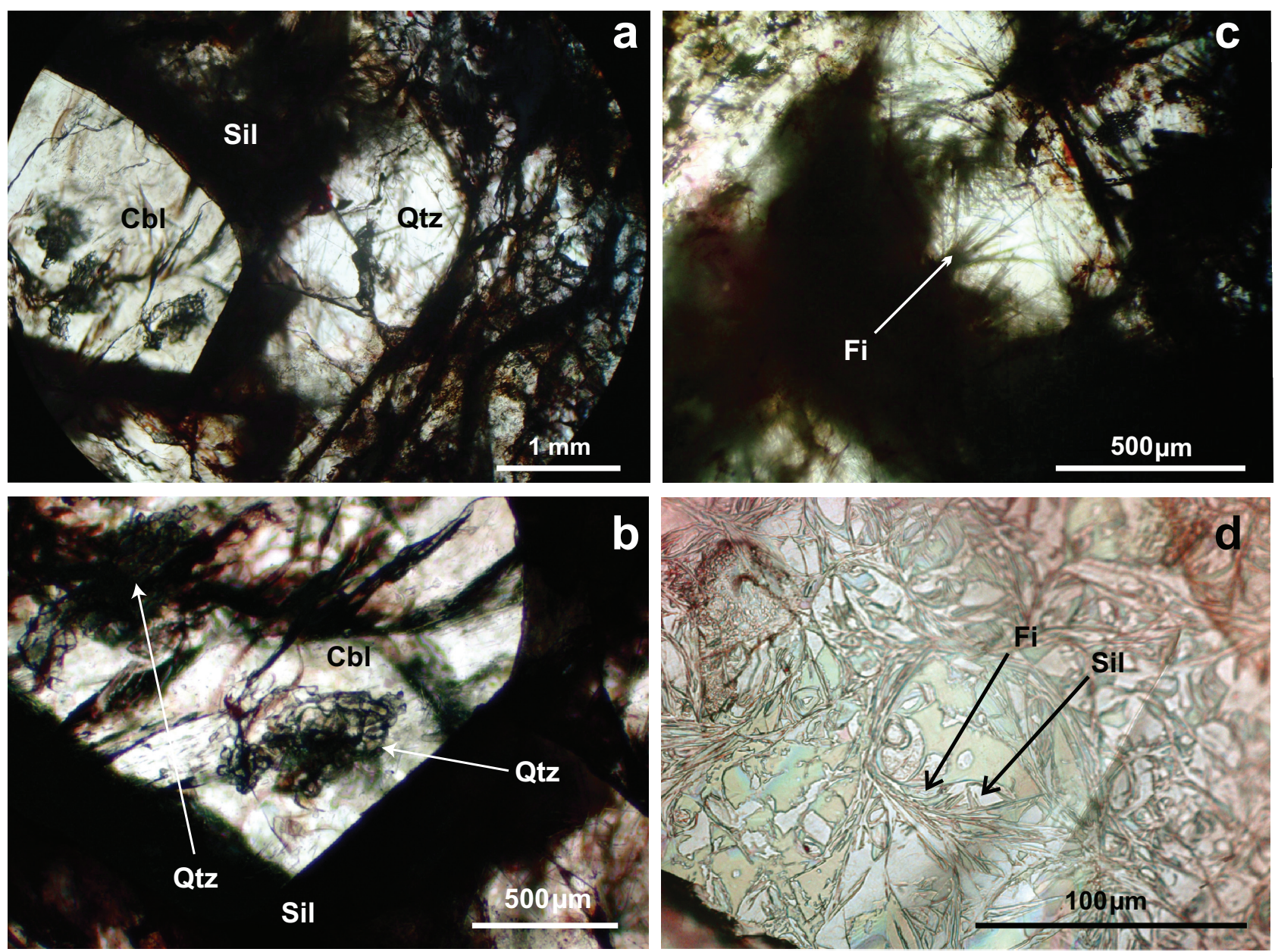

Fig. 4 Photomicrographs of thick polished sections: a - Sillimanite inclusions in quartz (Qtz) and in and around chrysoberyl (Cbl). The almost opaque area between quartz and chrysoberyl consists also of fibrous sillimanite (Sil); b - Detail of quartz inclusions (Qtz) in chrysoberyl. Arrows indicate the clusters of quartz inclusions in chrysoberyl; $\mathbf{c}$ - Radial aggregates of fibrolitic sillimanite inclusions (Fi) in quartz (colorless) from the shear zone; d - Dense network of fibrolitic sillimanite (Fi) and a few larger sillimanite crystals (Sil) included in chrysoberyl.

measurements for Fe (LIF), Cr (PET) and V (LIFH) were conducted with an operating voltage of $20 \mathrm{kV}$, a beam current of $20 \mathrm{nA}$, a beam diameter of $5 \mu \mathrm{m}$ and counting times up to $100 \mathrm{~s}$. The theoretical mass percent values of chrysoberyl were included in the matrix correction procedure. Limits of detection are: $\mathrm{Be}\left(\mathrm{K}_{\alpha}\right) 3950, \mathrm{Fe}\left(\mathrm{K}_{\alpha}\right) 240$, Al $\left(\mathrm{K}_{\beta}\right)$ 2350, Si $\left(\mathrm{K}_{\alpha}\right)$ 40, Ti 240, Cr 100, and V 32 (all in $\mathrm{ppm}$ ). The chrysoberyl formula (in atoms per formula unit - apfu) was calculated on the basis of 12 oxygens.

Raman spectra were recorded with a Jobin-Yvon LabRam HR800 spectrometer (grating: $1800 \mathrm{gr} / \mathrm{mm}$ ), equipped with an Olympus optical microscope and a long-working-distance LMPlanFI $100 \times / 0.80$ objective. We used a $514 \mathrm{~nm}$ excitation of a Coherent $\mathrm{Ar}^{+}$laser Model Innova 70C, a power of $300 \mathrm{~mW}$ (c. $45 \mathrm{~mW}$ on sample), at a resolution $\leq 0.6 \mathrm{~cm}^{-1}$. The spectra were collected at a constant laboratory temperature $\left(20^{\circ} \mathrm{C}\right)$ with a Peltier-cooled CCD detector and the positions of the Raman bands were controlled and eventually corrected using the principal plasma lines in the Argon laser. The difference between the recommended and measured positions of the plasma lines in the fingerprint spectral region did not exceed $0.6 \mathrm{~cm}^{-1}$ (see also Thomas and Davidson 2012).

The homogenization temperatures of fluid inclusions and the melting temperatures of their salt phases were performed with a calibrated LINKAM THMS 600 heating and freezing stage, together with a TMS92 temperature programmer and a LNP2 cooling system mounted on an Olympus microscope. The stage was calibrated with synthetic fluid inclusions (SYNFLINC) and melting points of different standards. All measurements were performed under argon atmosphere. The standard deviation depends on absolute temperature and was always less than $\pm 2.5^{\circ} \mathrm{C}$ for $\mathrm{T}>100^{\circ} \mathrm{C}$, and than $0.2^{\circ} \mathrm{C}$ for cryometric measurements at $\mathrm{T}<20^{\circ} \mathrm{C}$.

Powder X-ray diffraction (XRD) was performed using a D 5000 Siemens diffractometer and a $\mathrm{CuK}_{\alpha}$ tube, at the 
Department of Fundamental Chemistry of the Federal University of Pernambuco, Brazil.

The Secondary Electron Microscopy (SEM) analyses for preliminary identification of accessory minerals were carried out at the University of Campinas São Paulo using a Leo 430i, Cambridge, EDS mod. Cat. B, operating at $20 \mathrm{kV}$ and $30 \mathrm{~s}$ acquisition time. The following standards were used: Ta $\left.\left(\mathrm{Ta} \mathrm{M}_{\alpha}\right), \mathrm{Nb}\left(\mathrm{Nb} \mathrm{L}_{\alpha}\right), \mathrm{Sn}(\mathrm{Sn} \mathrm{L})_{\alpha}\right), \mathrm{Ti}(\mathrm{Ti}$ $\left.\mathrm{K}_{\alpha}\right), \mathrm{V}\left(\mathrm{VK}_{\alpha}\right), \mathrm{Sb}\left(\mathrm{SbL}_{\alpha}\right), \mathrm{Bi}\left(\mathrm{Bi} \mathrm{M}_{\alpha}\right) \mathrm{Zr}\left(\mathrm{Zr} \mathrm{L}_{\alpha}\right), \mathrm{U}\left(\mathrm{UM}_{\alpha}\right)$, $\mathrm{Hf}\left(\mathrm{Hf} \mathrm{M}_{\alpha}\right), \mathrm{PbF}_{2}\left(\mathrm{PbM}_{\alpha}\right)$, BCR2 ( $\mathrm{Fe} \mathrm{K}, \mathrm{Mn} \mathrm{K}_{\alpha}, \mathrm{Al} \mathrm{K}, \mathrm{Ca}$ $\left(\mathrm{K}_{\alpha}\right), \mathrm{Na}\left(\mathrm{K}_{\alpha}\right)$, Si $\left(\mathrm{K}_{\alpha}\right)$ and $\mathrm{K}\left(\mathrm{K}_{\alpha}\right)$.

\subsection{Analytical results}

The direct determination of Be with the electron microprobe confirmed clearly the correct identification as chrysoberyl. Selected representative analyses are listed in Tab. 1. The low total iron contents $(\mathrm{FeO}=1.25$ to 1.81 wt. \%), as well as $\mathrm{Cr}, \mathrm{V}$ and $\mathrm{Si}$ (mostly below the limits of detection) are in line with the pale yellowish-green color, good transparency, and the absence of dichromatism ("alexandrite effect") of the Cbl crystals. The oscillatory compositional zoning observed in the BSE image (Fig. 5) is due to the small variations of the iron content. A line scan from the center to the rim of a chrysoberyl crystal ( 92 points over a distance of $940 \mu \mathrm{m}$ ) showed that $\mathrm{Fe}$ is enriched in the core $(1.47 \pm 0.07 \%, \mathrm{n}=43)$, drops down in an intermediate zone $(1.36 \pm 0.07 \%, \mathrm{n}=13)$ and increases again in the $\operatorname{rim}(1.58 \pm 0.14 \%, \mathrm{n}=30)$. Aluminum contents rise slightly rimwards (from 80.1 \pm 0.4 to $81.7 \pm 0.4$ wt. $\%$ ). while Be shows no zoning $(\mathrm{BeO}=18.27$ wt. $\% \pm 0.39, \mathrm{n}=92)$. Taken together, the bulk average formula of the analysed $\mathrm{Cbl}$ crystal along the line scan, recalculated to 4 oxygens is: $\mathrm{Be}_{0.931 \pm 0.017}$ $\left(\mathrm{Al}_{2.028 \pm 0.011}, \mathrm{Fe}_{0.026 \pm 0.002}\right)_{\Sigma 2.054 \pm 0.013} \mathrm{O}_{4}( \pm 1 \sigma, \mathrm{n}=92)$.

The observed slight excess of total cations and $\mathrm{Al}$, as well as a slight depletion in Be compared with the ideal formula of $\mathrm{Cbl}$ is in disagreement with the idea of Weber et al. (2007) and Lottermoser et al. (2011) that all $\mathrm{Fe}$ (and $\mathrm{Cr}$ if present) substitutes for $\mathrm{Al}$ in the octahedral site. A similar depletion of Be was reported by Beus (1966, wet analyses) and Downes and Bevan (2002, EMPA - total cations normalized to 3.00 and calculated $\mathrm{Be}$ ) who also observed an excess in the total of octahedral cations.

The identity of chrysoberyl was verified, besides the EMP, by Raman spectroscopy and XRD. The measured powder XRD pattern of chrysoberyl from Roncadeira (Fig. S3) matches the RRUFF pattern no. R080110 of chrysoberyl from Sri Lanka and includes a few peaks of minor quartz (RRUFF pattern no.060604). The Raman spectrum of the Roncadeira (Fig. S4) chrysoberyl is almost identical with the reference spectrum X050037 of synthetic chrysoberyl in the RRUFF database (Downs 2006).

Tab. 1 Selected representative electron-microprobe analyses of chrysoberyl from Roncadeira, northeast Brazil

\begin{tabular}{|c|c|c|c|c|c|c|c|c|c|c|}
\hline \multirow[b]{2}{*}{ Id Nr. } & \multicolumn{5}{|c|}{ wt. $\%$ oxides } & \multicolumn{5}{|c|}{ Atoms per formula unit for $12 \mathrm{O}$} \\
\hline & $\mathrm{BeO}$ & $\mathrm{Al}_{2} \mathrm{O}_{3}$ & $\mathrm{SiO}_{2}$ & $\mathrm{FeO}$ & Total & $\mathrm{Be}$ & $\mathrm{Al}$ & $\mathrm{Si}$ & $\mathrm{Fe}$ & Total \\
\hline 54 & 18.36 & 79.92 & bdl & 1.74 & 100.02 & 2.832 & 6.050 & bdl & 0.093 & 8.975 \\
\hline 56 & 18.47 & 80.32 & bdl & 1.63 & 100.42 & 2.836 & 6.051 & bdl & 0.087 & 8.974 \\
\hline 57 & 18.37 & 79.49 & bdl & 1.81 & 99.67 & 2.844 & 6.039 & bdl & 0.098 & 8.981 \\
\hline 59 & 18.27 & 79.96 & bdl & 1.80 & 100.03 & 2.820 & 6.055 & bdl & 0.097 & 8.972 \\
\hline 61 & 18.41 & 80.59 & bdl & 1.75 & 100.75 & 2.820 & 6.058 & bdl & 0.094 & 8.972 \\
\hline 62 & 18.46 & 79.75 & bdl & 1.64 & 99.85 & 2.850 & 6.041 & bdl & 0.088 & 8.979 \\
\hline 63 & 18.78 & 80.44 & bdl & 1.58 & 100.80 & 2.870 & 6.031 & bdl & 0.084 & 8.985 \\
\hline 65 & 18.45 & 79.89 & bdl & 1.59 & 99.93 & 2.845 & 6.046 & bdl & 0.086 & 8.977 \\
\hline 66 & 19.19 & 79.60 & bdl & 1.54 & 100.33 & 2.941 & 5.985 & bdl & 0.082 & 9.008 \\
\hline 68 & 18.63 & 80.78 & bdl & 1.52 & 100.93 & 2.844 & 6.050 & bdl & 0.081 & 8.975 \\
\hline 79 & 18.90 & 80.46 & bdl & 1.54 & 100.90 & 2.884 & 6.023 & bdl & 0.082 & 8.989 \\
\hline 80 & 18.39 & 80.46 & bdl & 1.52 & 100.37 & 2.825 & 6.063 & bdl & 0.081 & 8.969 \\
\hline 82 & 18.48 & 81.07 & bdl & 1.41 & 100.96 & 2.820 & 6.070 & bdl & 0.075 & 8.965 \\
\hline 86 & 18.30 & 81.01 & 0.006 & 1.28 & 100.59 & 2.802 & 6.086 & 0.000 & 0.068 & 8.957 \\
\hline 89 & 19.06 & 80.36 & bdl & 1.38 & 100.80 & 2.907 & 6.013 & bdl & 0.073 & 8.993 \\
\hline 130 & 18.30 & 80.88 & bdl & 1.54 & 100.72 & 2.803 & 6.077 & bdl & 0.082 & 8.962 \\
\hline 157 & 18.59 & 79.92 & bdl & 1.60 & 100.11 & 2.861 & 6.035 & bdl & 0.086 & 8.982 \\
\hline 158 & 18.49 & 80.16 & bdl & 1.51 & 100.16 & 2.844 & 6.050 & bdl & 0.081 & 8.975 \\
\hline 159 & 18.68 & 80.26 & bdl & 1.51 & 100.45 & 2.864 & 6.037 & bdl & 0.080 & 8.981 \\
\hline 161 & 18.34 & 80.91 & 0.008 & 1.61 & 100.87 & 2.805 & 6.072 & 0.001 & 0.086 & 8.964 \\
\hline
\end{tabular}

Limits of detection (ppm) are $\mathrm{Be}\left(\mathrm{K}_{\alpha}\right)$ 3950, $\mathrm{Fe}\left(\mathrm{K}_{\alpha}\right)$ 240, $\mathbf{A l}\left(\mathbf{K}_{\beta}\right)$ 2350, $\mathrm{Si}\left(\mathrm{K}_{\alpha}\right)$ 40, Ti 240, Cr 100 and V 32.

\begin{tabular}{|c|c|c|c|c|c|c|c|c|c|c|}
\hline Average $(n=92)$ & 18.30 & 81.24 & 0.002 & 1.48 & 100.53 & 2.793 & 6.085 & 0.00014 & 0.079 & 8.957 \\
\hline $1 \sigma$ & 0.39 & 0.68 & 0.003 & 0.12 & 0.68 & 0.051 & 0.034 & 0.000 & 0.007 & 0.017 \\
\hline
\end{tabular}




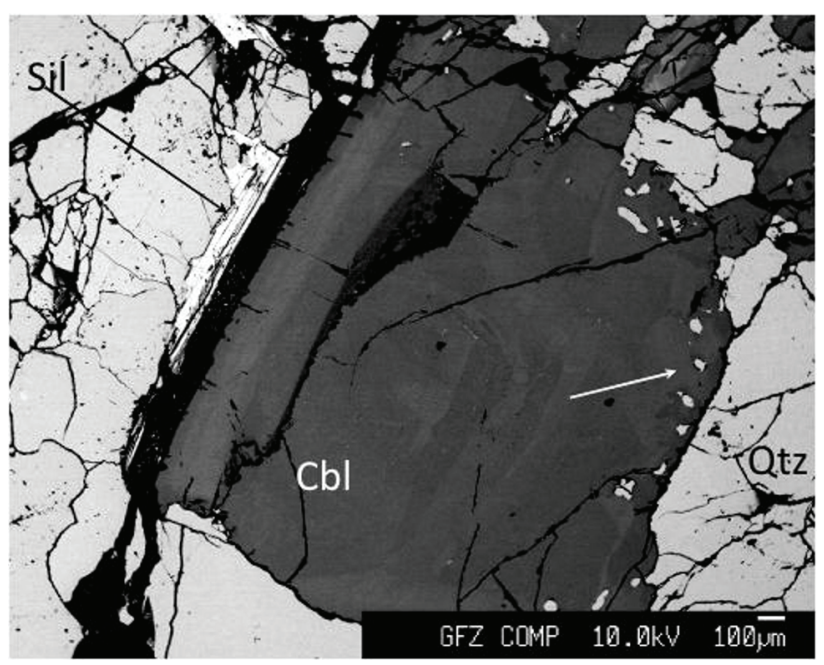

Fig. 5 Back-scattered electron (BSE) image of the chrysoberyl + quartz + sillimanite assemblage. Note the skeletal growth of the chrysoberyl crystal (dark, in the center of the photo) with common quartz inclusions along the upper-right crystal rim (white arrow) and at the left a fibrous sillimanite aggregate indicated by the black arrow. The oscillatory zoning is due to slightly higher Fe contents in the lighter zones. The Cbl crystal is the same as on Fig. $4 \mathrm{~b}$.

The quartz grains in the sodic aplite portion in one sample according to fluid inclusion study contain two principal fluid inclusion types: (i) nearly pure $\mathrm{CO}_{2}$-rich fluid inclusions with highly variable densities and (ii) rare and very small nahcolite-rich fluid inclusions (Fig. S2), which homogenize at $c .400{ }^{\circ} \mathrm{C}$ in the fluid phase. With respect to high $\mathrm{CO}_{2}$ activity and homogenization temperatures, our preliminary results resemble those reported by Soman and Nair (1985) from Cbl occurrences in pegmatites from Kerala, India, and Petersen et al. (2002) in kyanite-garnet-mica schists and quartzites from Minaçu, State of Goiás, Brazil. The primary pegmatitic origin of the $\mathrm{Cbl}$ was presumed by the former authors, while the metamorphic origin was proposed for the Brazilian occurrence. The $\mathrm{P}-\mathrm{T}$ conditions for the $\mathrm{Cbl}$ crystallization nearly overlap for both cases.

\section{Discussion}

\subsection{Types of pegmatite-related chrysoberyl occurrences}

According to Černý (2002), the occurrence of primary chrysoberyl in pegmatites (primary meaning crystallized directly from the pegmatite melt) is usually restricted to high-T pegmatites with low to moderate degree of fractionation. Chrysoberyl occurrences of this type (from now on Type 1) were reported worldwide \{e.g. by Moore and Ito (1973) from Black Hills, South Dakota, USA, by Gonzales del Tánago (1991) from Sierra Al- barana, Spain, by Soman and Nair (1985) from Kerala, India and by Žáček and Vrána (2002) from Kalanga Hill, NE Zambia\}. Cassedanne (1991) described the Type 1 chrysoberyl from multiple localities in the State of Espírito Santo, Brazil, e.g. Santa Tereza and Castelinho pegmatites, and many others in the states of Minas Gerais and Bahia.

The formation of chrysoberyl in, or related to, well differentiated pegmatites (e.g. REL-class sensu Černý and Ercit 2005), is usually explained by desilication of the pegmatite due to interaction with host rocks rich in $\mathrm{Al}_{2} \mathrm{O}_{3}$ (e.g. metapelites) or poor in $\mathrm{SiO}_{2}$, such as maficultramafic rocks. These are characterized as "desilicated pegmatites" (distinguished from now on as Type 2). Furthermore, Černý (2002), in agreement with Fersman (1952), Beus (1966) and Okrusch (1971), included in this group genetically similar occurrences hosted in "phlogopite selvages" of pegmatites (Subtype 2A) and also those in veins or phlogopite masses ("black schist walls") crosscutting "ultramafic rocks" in the neighborhood of pegmatites or granites which served as Be-sources (Subtype 2B). The latter are typical of most of the alexandrite occurrences. This gemological variety of chrysoberyl needs an additional source of $\mathrm{Cr}$ (sometimes also V), an element most frequently responsible for the "alexandrite effect" (Schmetzer et al. 1980; Malsy and Armbruster 2012 and references therein).

However, the distinction of subtypes $2 \mathrm{~A}$ and $2 \mathrm{~B}$ is still not sufficient (with regard to the sources of Be and $\mathrm{Cr}$, and timing of $\mathrm{Cbl}$ formation) to cover the variations of deposits found in the literature within the general category of "desilicated pegmatite" deposits. Franz and Morteani (1981,1984 and 2002) demonstrated the possibility of a metamorphic formation of chrysoberyl + quartz under high-grade metamorphic conditions instead of beryl based on both experimental work and textural evidence in several chrysoberyl occurrences. In the case of Habachtal, Austria, metamorphosed volcano-sedimentary rocks (rhyolitic metatuffs, and not pegmatites or granites) are supposed to be the Be source, which was tectonically juxtaposed to previously metamorphosed ultramafic rocks (Grundmann and Morteani 1989; Grundmann and Koller 2003). Both chrysoberyl and emerald were formed presumably by a late-kinematic high-grade metamorphic-metasomatic process along a shear-zone (Subtype 2C). The timing of the alexandrite (and emerald) formation in such deposits is not related to granite or pegmatite intrusions, and completely different from the case of sub-types $2 \mathrm{~A}$ and $2 \mathrm{~B}$. In addition, a late formation of chrysoberyl at subsolidus, metasomatic-hydrothermal conditions, related to "albite veins" which cross-cut REL-class pegmatites at Cap de Creus, Catalonia, Spain, was suggested by Alfonso et al. (1995) and Alfonso and Melgarejo (2008). This example 
could be distinguished as Subtype 2D because in this case the hydrothermal chrysoberyl formation occured within pegmatites under very low $\mathrm{SiO}_{2}$ and high $\mathrm{Al}_{2} \mathrm{O}_{3}$ activities in the system. Such conditions resemble those required for the "desilicated pegmatites" but the subtype $2 \mathrm{D}$ is unrelated to mafic host rocks.

Based on Franz and Morteani (1981, 1984 and 2002), Černý (2002) distinguished the metamorphic chrysoberyl in pegmatites as a third type of deposits. In these cases (e.g. Kolsva - Sweden and Maršíkov - Czech Republic) the $\mathrm{Cbl}$ grew during the deformation of beryl-bearing pegmatites under medium- or high-grade (at least amphibolite-facies) regional metamorphic conditions. The process involved a progressive metamorphic destabilization of beryl, which reacted with feldspar or muscovite to form chrysoberyl + quartz + aluminosilicates along with fluid or melt (Type 3A). A special variety of this type was recently described by Galliski et al. (2012) from Virorco, Argentina, where chrysoberyl grew after beryl during metamorphic overprint of highly fractionated and boron-rich thin pegmatite veins.

In some occurrences, $\mathrm{Cbl}$ (including alexandrite) is found in high-grade (granulite) metamorphic terrains, supposedly as a prograde regional metamorphism product, but without a well-established Be source (e.g. at Dowerin, Australia; Downes and Bevan 2002) and could be distinguished as Type 3B. Grew et al. (2000) identified another chrysoberyl occurrence also supposedly formed at granulite-facies metamorphic conditions, in this case hosted in pegmatite veinlets supposed to be the first partial melt of metapelites. An association of chrysoberyl with high-grade granulite and charnockite terrains was also highlighted by many authors for occurrences in India, Sri Lanka and Madagascar (e.g. Munasinghe and Dissanayake 1981; Rupasinghse et al. 1984; Manimaran et al. 2007 and references therein).

Alluvial and elluvio-colluvial concentrations of chrysoberyl (Type 4) may be derived from any of the former types and are economically very important as gem sources.

The known Brazilian findings and deposits of chrysoberyl, including those of alexandrite and cats eye varieties, according to Bank et al. (1987), Proctor (1988), Cassedanne (1991), Cassedanne and Roditi (1993) are of types 1, 2A, 2B and 4. In addition Petersen Jr. et al. (2002), Rocha (2003) and Schultz-Güttler et al. (2010) described a metamorphic occurrence of chrysoberyl (+ alexandrite) porphyroblasts in highgrade metasedimentary rocks (kyanite + staurolite + garnet quartzites with thin amphibolite intercalations), $600 \mathrm{~m}$ south of the contact with the Mesoproterozoic Serra Dourada (c. 1.6 Ma) granite in the State of Goiás (similar to Type 3B).

\subsection{Comparison of Roncadeira with other chrysoberyl occurrences}

The occurrence of chrysoberyl at Roncadeira is the first reported in the Borborema Pegmatite Province and, according to the textural relations described above, seems to be the first of type 3A in Brazil (metamorphic $\mathrm{Cbl}$ in deformed pegmatites, similar to Maršíkov and Kolsva).

Among several reactions proposed by Franz and Morteani $(1984,2002)$ for the metamorphic formation of chrysoberyl in pegmatites, the one below seems to best represent the textural relations observed at Roncadeira: beryl + albite + muscovite $+\mathrm{H}^{+} \leftrightarrow$ chrysoberyl + quartz + sillimanite $+\mathrm{Na}^{+}+\mathrm{K}^{+}+\mathrm{H}_{2} \mathrm{O}$.

The absence of beryl relics in the studied samples and thin sections indicates its complete consumption during this reaction, which is in contrast with the cases described by Franz and Morteani (1984) and Černý et al. (1992) at Kolsva and Maršíkov, respectively, where the newly formed chrysoberyl frequently enclosed relics of the replaced primary beryl.

Another possible explanation for the chrysoberyl formation in the Roncadeira pegmatite is highly favored by one of the authors (RT). This is the simple substitution reaction:

$$
\mathrm{Al}_{2} \mathrm{SiO}_{5}+\mathrm{Be}(\mathrm{OH})_{2} \text { (aq.) } \leftrightarrow \mathrm{Al}_{2} \mathrm{BeO}_{4}+\mathrm{SiO}_{2}+\mathrm{H}_{2} \mathrm{O}
$$

where sillimanite would have been formed earlier than chrysoberyl. The source/origin of $\mathrm{BeO}$ or $\mathrm{Be}(\mathrm{OH})_{2}$ in this case could be a previous hydrothermal destabilization of beryl in the pegmatite or an unknown Be-bearing mineral (muscovite?) in the host rocks.

According to this scheme, sillimanite $\left[\mathrm{Al}_{2} \mathrm{SiO}_{5}\right]$ reacts at temperatures $c .600^{\circ} \mathrm{C}$ with the highly mobile $\mathrm{Be}$ species (see Thomas and Davidson 2010) and forms the chrysoberyl. This mechanism is supported by following observations: (i) beryl is completely absent in the samples with chrysoberyl; (ii) chrysoberyl occurs only along, or near, shear surfaces along which the Be-bearing solutions supposedly moved; (iii) chrysoberyl in such zones replaces sillimanite fibroblasts; (iv) chrysoberyl is rich in inclusions of relict (corroded) and new-formed sillimanite crystals forming a dense network (Fig. 4d); (v) fine-grained quartz clusters Fig. $4 c$ enclosed in the chrysoberyl crystals are supposedly products of the reaction of the precursor sillimanite to form the chrysoberyl. Furthermore, the second point underlines the remark by Černý $(2002$, p. 408) that "chrysoberyl is favored in shear-stressed environments associated with sillimanite".

It is noteworthy that the association of chrysoberyl + quartz + sillimanite with minor gahnite and nigeritegroup minerals similar to that described from Roncadeira was also observed at Egbe, Nigeria, "in quartz-sillimanite rock units" along the contact of albite-rich pegmatites with the host-rock gneisses (type locality for nigerite, 
Jacobson and Webb 1947). Similar assemblage of nigerite with chrysoberyl \pm aluminosilicates and gahnite was found in heavy mineral concentrates in the first nigerite occurrence in Brazil, State of Amapá (Kloosterman 1944).

\subsection{Estimates of $P-T$ conditions for Roncadeira and metallogenetic implications}

Černý et al. (1992) estimated the metamorphic formation of the chrysoberyl + sillimanite + quartz association at expense of beryl + albite + muscovite in the Maršíkov pegmatite in the Czech Republic by deformation at 570 $630^{\circ} \mathrm{C} / 2.5-4.0 \mathrm{kbar}$. This was based on the sillimanite stability field and the combination of several calibrated progressive metamorphic reactions (formation of sillimanite at expense of muscovite or albite and of chrysoberyl + quartz at expense of beryl, Franz and Morteani 1981; Barton 1986) coherent with their textural observations. These estimated $\mathrm{P}-\mathrm{T}$ conditions agreed well with the regional metamorphic conditions of the hosting gneisses, albeit at slightly lower pressures (Černý et al. 1992).

As in the Roncadeira occurrence, at Maršíkov the formation of the high grade Cbl-Qtz-Sil association was not pervasive but took place preferentially along deformation zones and surfaces. The possible stress-induced growth of fibrolitic sillimanite under metastable, lower T conditions as postulated by Eugster (1970), Vernon (1979, 1987), Wintsch (1975), Wintsch and Andrews (1988) and Kerrick (1987, down to $490{ }^{\circ} \mathrm{C}$, in the andalusite stability field) perhaps could have had some influence on the P-T estimates above. The assumption of low-T, metastable sillimanite formation in presence of fluids, however, is incompatible with the presence of well crystallized chrysoberyl, stable at low temperatures only in dry systems and low Si activity (Barton and Young 2002). In addition, recent papers dealing with petrogenesis of fibrolite always has invoked formation within the stability field of sillimanite (e.g. Musumeci 2002; Kim and Bell 2005; Goergen et al. 2008). Therefore the model of the sillimanite formation in the Roncadeira pegmatite in the Sil stability field is preferred here.

The up to now usually accepted genetic model for Ta, $\mathrm{Be}, \mathrm{Li}$, and Sn-bearing REL-class granitic pegmatites of the BPP assumed that these pegmatites were emplaced in extensional fractures (WNW-striking) or in reactivated strike-slip shear zones (NNE) (Araújo et al 2001, 2005 and references therein). As discussed already, there is a general agreement that this emplacement occurred at a late stage under greenschist-facies regional metamorphic conditions, post-dating by more than 40 My the amphibolite-facies metamorphic peak in the host rocks at 560 to $600 \mathrm{Ma}$ (Araújo et al 2001, 2005; Baumgartner et al. 2006; Beurlen et al. 2008).
If the coexistence of $\mathrm{Cbl}+\mathrm{Sil}+\mathrm{Qtz}$ is a typical amphibolite- to granulite-grade metamorphic paragenesis in (or related to) pegmatites elsewhere (Franz and Morteani 1984, 2002; Černý et al. 1992), its recognition in the Roncadeira pegmatite seems to be in disagreement with the current one-stage model of REL-pegmatite genesis in the BPP.

Alternative explanations are:

1. Roncadeira represents an earlier generation of granitic REL-class pegmatites in the BPP, synchronous with the amphibolite-grade metamorphic peak in the Seridó Belt, at c. 560 to $600 \mathrm{Ma}$;

2. A second, recurrent late-stage amphibolite-facies metamorphism occurred at c. 500 to $520 \mathrm{Ma}$, i.e. after the retrometamorphic greenschist-facies overprint;

3. The $\mathrm{Cbl}+\mathrm{Sil}+\mathrm{Qtz}$ paragenesis at Roncadeira represents a "stress induced metastable" association formed at regional greenschist-facies metamorphic conditions.

The stability of chrysoberyl + quartz was established at a minimum temperature of $430^{\circ} \mathrm{C}$ at $4 \mathrm{kbar}$ for dry to $560^{\circ} \mathrm{C}$ at $5 \mathrm{kbar}$ for water-saturated conditions by Barton (1986) and Barton and Young (2002). Stability of chrysoberyl at even lower temperatures is restricted to very low $\mathrm{SiO}_{2}$ activities (Barton and Young 2002), i.e. not applicable in the present case where the chrysoberyl formed in equilibrium with quartz. Therefore, a metastable origin of the well-formed cm-large Cbl-crystals at Roncadeira together with also metastable fibrolitic sillimanite seems as unlikely as the metastable fibrolite formation alone. Alternative 3 can be therefore discarded.

The choice between alternatives 1 or 2 needs more detailed field observations and geochronological support, for these particular pegmatites that differ from most other REL-class pegmatites in the BPP by the dominance of cassiterite in the ore mineral assemblage.

Independently of which alternative is correct, it is important to point out that the identification of chrysoberyl at Roncadeira opens a perspective for the existence of alexandrite occurrences in the area, at localities where pegmatites cross-cut orthoamphibolite intercalations in the Seridó Formation, as recognized by Beurlen and Busch (1982) and Beurlen (1985).

\section{Conclusions}

A metamorphic origin of chrysoberyl (Cbl), found as accessory mineral in the Roncadeira pegmatite, a former cassiterite prospect in Nova Palmeira County (State of Paraíba) in the Borborema Pegmatite Province is postulated. The paragenesis and textural relations suggest a synkinematic origin under high-grade metamorphic conditions, related to shear zones, by the reaction: 
beryl + albite + muscovite $\rightarrow$ chrysoberyl + quartz + sillimanite + fluid + alkalies.

According to this reaction, beryl + muscovite + albite represent the primary orthomagmatic paragenesis of the banded aplite facies in the pegmatite and sillimanite + chrysoberyl + quartz are products of metamorphism, clearly restricted to small centimeter-thick shear zones.

The $\mathrm{Cbl}$ has low Fe concentrations (below 1.8 wt. \% $\mathrm{FeO}^{\text {tot }}$ ) and very low (mostly below the limits of detection) contents of $\mathrm{Cr}$, $\mathrm{V}$ and $\mathrm{Ti}$.

The presence of similar pegmatites (albitic and stanniferous) and the existence of intercalations of orthoamphibolites in the pegmatite hosting biotite schists of the Serido Formation north of Roncadeira, opens the perspective for the occurrence of alexandrite in the area along the eastern limb of the Serra dos Quintos antiform.

Acknowledgements. This research was supported by $\mathrm{CNPq}$ (Conselho Nacional do Desenvolvimento Científico e Tecnológico), grants APQ 471064/2006-8 \& 302-348/2007-7. The free use of the EMP and Raman facilities in the Helmholtz Foundation, GeoForschungs Zentrum Potsdam, Germany, are greatly acknowledged. We dedicate this paper to Milan Novák whose scientific work is an example for everyone who wants to focus his research on granitic pegmatites. The authors gratefully appreciate the thorough review and constructive criticism and comments by Jan Cempírek and Vladimír Žáček and editorial handling by Radek Škoda and Vojtěch Janoušek, which improved much the first version of this contribution.

Electronic supplementary material. Additional photomicrographs, together with X-ray diffraction pattern and Raman spectrum of the Roncadeira chrysoberyl, are available online at the Journal web site (http://dx.doi. org/10.3190/jgeosci.142).

\section{References}

Alfonso PA, Melgarejo JC (2008) Fluid evolution in the zoned rare-element pegmatite field at Cap De Creus, Catalonia, Spain. Canad Mineral 46: 597-617

Alfonso PA, Corbela MC, Melgarejo JC (1995) Nb-Taminerals from the Cap de Creus pegmatite field, eastern Pyrenees. Mineral Petrol 55: 53-69

Araújo MNC, Alves da Silva FC, Jardim de Sá EF (2001) Pegmatite emplacement in the Seridó Belt, northeastern Brazil: late stage kinematics of the Brasiliano Orogen. Gondwana Res 4: 75-85

Araújo MNC, Vasconcelos PM, Silva FCA, Jardim de SÁ EF, SÁ JM (2005) ${ }^{40} \mathrm{Ar} /{ }^{39} \mathrm{Ar}$ geochronology of gold mineralization in Brasiliano strike-slip shear zones in the Borborema Province, NE Brazil. J South Am Earth Sci 19: 445-460

ARMSTRONG JT (1995) CITZAF: a package of correction programs for the quantitative electron microbeam X-ray analysis of thick polished materials, thin films, and particles. Microbeam Analysis 4: 177-200

Bank FH, Bank H, Gübelin E, Henn U (1987) Alexandrite aus einem neuen Vorkommen bei Hematita in Minas Gerais, Brasilien. Z Dtsch Gemmol Ges 36: 121-131

BARTON MD (1986) Phase equilibria and thermodynamic properties of minerals in the $\mathrm{BeO}-\mathrm{Al}_{2} \mathrm{O}_{3}-\mathrm{SiO}_{2}$ (BASH) system with petrologic applications. Amer Miner 71: 277-300

BARTON MD, Young S (2002) Non-pegmatitic deposits of beryllium: mineralogy, geology, phase equilibria and origin. In: GrEw ES (ed) Beryllium: Mineralogy, Petrology, and Geochemistry. Mineralogical Society of America Reviews on Mineralogy 50: 591-691

Baumgartner R, Romer RL, Moritz R, Sallet R, Chiaradia M. (2006) Columbite-tantalite-bearing granitic pegmatites from the Seridó Belt, northeastern Brazil: genetic constraints from $\mathrm{U}-\mathrm{Pb}$ dating and $\mathrm{Pb}$ isotopes. Canad Mineral 44: 69-86

Beurlen H (1985) “Tactites” formed by Ca-Al-metasomatism on amphibolites in the Seridó Scheelite Province NE Brazil. In: Wauschkuhn A, Kluth C, Zimmermann RA (eds) Syngenesis and Epigenesis in the Formation of Mineral Deposits. Springer, Berlin, pp 598-607

Beurlen H, Busch K (1982) Orthoamphibolitic tungsten proto-ore in the Seridó Scheelite Province, State of Rio Grande do Norte, NE-Brazil (Protominério de tungstenio ortoanfibolitico na Província Scheelitifera do Seridó, Rio Grande do Norte, Nordeste do Brazil). Actas Quinto Congreso Latinoamericano de Geologia Buenos Aires 2: 69-81 (in Portuguese)

Beurlen H, Barreto SB, Silva D, Wirth R, Olivier P (2007) Titanian ixiolite-niobian rutile intergrowths from the Borborema Pegmatitic Province, Northeastern Brazil. Canad Mineral 45: 1367-1387

Beurlen H, Da Silva MRR, Thomas R, Soares DR, Olivier $\mathrm{P}$ (2008) Nb-Ta-(Ti-Sn)-oxide mineral chemistry as tracers of rare-element granitic pegmatite fractionation in the Borborema Province, northeastern Brazil. Miner Depos 43: 207-228

Beus AA (1966) Geochemistry of Beryllium and Genetic Types of Beryllium Deposits. Freeman \& Co, San Francisco, pp 1-401

Cassedanne J (1991) Tipologia das jazidas brasileiras de gemas (Typology of the Brazilian gem deposits). In: Schobbenhaus C Queiroz ET, Coelho CES (eds) Main Mineral Deposits of Brazil (Principais Depósitos Minerais do Brasil), Vol IV(A). Departamento Nacional da Produção Mineral-DNPM (Brazilian Geological Survey), Brasília, Brazil, pp 17-52 (in Portuguese) 
Cassedanne J, Roditi M (1993) The location, geology, mineralogy and gem deposits of alexandrite, cat's-eye and chrysoberyl in Brazil. J Gemm 23: 333-354

ČERNÝ P (2002) Mineralogy of beryllium in granitic pegmatites. In: Grew ES (ed), Beryllium: Mineralogy, Petrology and Geochemistry. Mineralogical Society of America Reviews on Mineralogy 50: 406-444

ČERNÝ P, ERCiT TS (2005) The classification of granitic pegmatites revisited. Canad Mineral 43: 2005-2026

ČERnÝ P, NovÁk M, ChapMan R (1992) The effects of sillimanite-grade metamorphism and shearing on $\mathrm{Nb}-$ Ta oxide minerals in pegmatites: Maršíkov, northern Moravia, Czechoslovakia. Canad Mineral 30: 699-718

DA SILVA MRR (1993) Petrographical and geochemical investigations of pegmatites in the Borborema Pegmatitic province of northeastern Brazil. Unpublished Ph.D. thesis, Ludwig Maximilian Universität, München, pp 1-135

Downs RT (2006) The RRUFF Project: an integrated study of the chemistry, crystallography, Raman and infrared spectroscopy of minerals. Program and Abstracts of the $19^{\text {th }}$ General Meeting of the International Mineralogical Association in Kobe, Japan. O03-13 http://rruff.info/about/about_general.php

Downes PJ, Bevan AW (2002) Chrysoberyl, beryl and zincian spinel mineralization in granulite-facies Archean rocks at Dowerin, Western Australia. Mineral Mag 66: 985-1002

Eugster HP (1970) Thermal and ionic equilibria among muscovite, K-feldspar and alumosilicate assemblages. Fortschr Mineral 47: 106-123

Fersman AA (1952) Pegmatites. Les Pegmatites Granitiques. University of Louven and Brussels, French translation from the Russian $1^{\text {st }}$ edition (1931), pp 1-671

Franz G, Morteani G (1981) The system $\mathrm{BeO}-\mathrm{Al}_{2} \mathrm{O}_{3}-\mathrm{SiO}_{2}-$ $\mathrm{H}_{2} \mathrm{O}$ : hydrothermal investigation of the stability of beryl and euclase in the range from 1 to $6 \mathrm{~kb}$ and 400 to $800^{\circ} \mathrm{C}$. Neu Jb Mineral, Abh 140: 273-299

Franz G, Morteani G (1984) The formation of chrysoberyl in metamorphosed pegmatites. J Petrol 25: 27-52

Franz G, Morteani G (2002) Be-minerals: synthesis, stability, and occurrence in metamorphic rocks. In: GREw ES (ed) Beryllium: Mineralogy, Petrology and Geochemistry. Mineralogical Society of America Reviews on Mineralogy 50: 551-589

Galliski MÁ, Márquez-Zavalía MF, Lira R, Cempírek J, ŠKODA R (2012) Mineralogy and origin of dumortieritebearing pegmatites of Virorco, San Luis, Argentina. Canad Mineral 50: 873-894

Goergen ET, Whitney DL, Zimmerman ME, Hiraga T (2008) Deformation-induced polymorphic transformation: experimental deformation of kyanite, andalusite, and sillimanite. Tectonophysics 454: 23-35

GonZAles del TANAGO J (1991) Las pegmatitas graníticas de Sierra Albarrana (Córdoba, España); mineralizaciónes de berilio. Bol Geol Minero 102: 578-603 (in Spanish)
Grew ES, Yates MG, Barbier J, Shearer CK, Sheraton JW, Shiraishi K Мотоуоsнi Y (2000) Granulite-facies beryllium pegmatites in the Napier Complex in Khmara and Amundsen bays, western Enderby Land, East Antarctica. Polar Geosci 13: 1-40

Grundmann G, Koller F (2003) Exkursion: das Smaragdbergwerk im Habachtal, Land Salzburg, Österreich. Mitt Österr Mineral Gesell 148: 317-343

GrundMANN G, MorTEANi G (1989) Emerald mineralization during regional metamorphism: the Habachtal (Austria) and Leydsdorp (Transvaal, South Africa) deposits. Econ Geol 84: 1835-1849

JACOBSON R, WeBB JS (1947) The occurrence of nigerite, a new tin mineral in quartz sillimanite rocks from Nigeria. Mineral Mag 28: 118-128

KERRICK DM (1987) Fibrolite in contact aureoles of Donegal, Ireland. Amer Miner 72: 240-254

Kim H S, Bell TH (2005) Multiple foliations defined by different sillimanite crystal habits, partial melting and the late metamorphic development of the Cannington $\mathrm{Ag}-\mathrm{Pb}-\mathrm{Zn}$ Deposit, Northeast Australia. Gondwana Res 8: 493-509

Kloosterman JB (1944) Nigerite in the tin-tantalum pegmatites of Amapá, Brazil. Mineral Mag 39: 837-846

Lottermoser W, Redhammer GJ, Weber SU, Litterst FJ, Tippelt G, Dlugosz S, Bank H, Amthauer G, Grodzicki M (2011) The electric field gradient in natural iron-doped chrysoberyl $\mathrm{Al}_{2} \mathrm{BeO}_{4}$ and sinhalite $\mathrm{MgAlBO}_{4}$ single crystals. Phys Chem Miner 38: 787-799

Malsy A, Armbruster T (2012) Synthetic alexandrite growth methods and their fingerprints. Eur J Mineral 24: $153-162$

Manimaran G, Bagai D, Roy-Chacko PT (2007) Chrysoberyl from Southern Tamil Nadu of South India with implications for Gondwana studies. In: RaJENDRAN S, Aravindan S and Srinivasamoorthy K (eds) Mineral Exploration: Recent Strategies. New India Publishing Agency, New Delhi, pp 63-76

Moore PB, Ito J (1973) Wyllieite, $\mathrm{Na}_{2} \mathrm{Fe}^{2+}{ }_{2} \mathrm{Al}_{(}\left(\mathrm{PO}_{4}\right)_{3}$, a new species. Mineral Rec 4: 131-136

Munasinghe T, Dissanayake CB (1981) The origin of gemstones of Sri Lanka. Econ Geol 76: 1216-1225

MUSUMECI G (2002) Sillimanite in shear zones in syntectonic leucogranite: fluid assisted brittle-ductile deformation under amphibolite facies conditions. J Struct Geol 24: $1495-1505$

ОкRUSCh M (1971) Zur Genese von Chrysoberyll- und Alexandrit-Lagerstätten. Eine Literaturübersicht. Z Dtsch Gemmolog Ges 20:114-124

Petersen JR KJ, Schulz-Güttler RA, Bello RM (2002) Alexandrita do Pela Ema, Minaçu/ GO: inclusões fluidas e condições genéticas. Rev Bras Geociências 32: 307-316 (in Portuguese) 
Proctor K (1988) Chrysoberyl and alexandrite from the pegmatite district of Minas Gerais, Brazil. Gems Gemol 24: $16-32$

Rocha GA (2003) Petrology and genesis of the alexandrite mineralization in the southern border of the the Serra Dourada Granite Massif (GO) (Petrologia e gênese da mineralização de alexandrita na borda sul do maciço granítico Serra Dourada (GO)). Unpublished MSc. thesis, Universidade Nacional de Brasília, pp 1-122 (in Portuguese)

Rollf P (1946) Mineral reserves of the Picuí County (Reservas minerais do Município de Picuí). Departamento Nacional da Produção Mineral (Brazilian Geological Survey) - Divisão de Fomento e Produção Mineral-DFPM, Boletim 80: pp 1-54 (in Portuguese)

Roy PL, Dottin O, Madon HL (1964) Estudo dos pegmatitos do Rio Grande do Norte e da Paraíba (Study of the pegmatites of the states of Rio Grande do Norte e Paraíba). Superintendência de Desenvolvimento do Nordeste (SUDENE), Série Geol Econ 1: pp 1-124 (in Portuguese)

Rupasinghse MS, Bannerjee A, Pense J, Dissanayake CB (1984) The geochemistry of beryllium and fluorine in gem fields of Sri Lanka. Miner Depos 19: 86-93

Schmetzer K, Bank H, GüBelin E (1980) The alexandrite effect in minerals: chrysoberyl, garnet, corundum, fluorite. Neu Jb Miner, Abh 138:147-164

Schultz-Güttler R, Petersen JR KJ, Henn U (2010) Alexandrite von Minaçu, Goias, Brasilien: ein primäres Vorkommen. Z Dtsch Gemmolog Ges 59: 63-74

SOMAN K, NAIR NGK (1985) Genesis of chrysoberyl in the pegmatites of Southern Kerala, India. Mineral Mag 49: 733-738
Thomas R, Davidson P (2010) Hambergite-rich melt inclusions in morganite crystals from the Muiane pegmatite, Mozambique and some remarks on the paragenesis of hambergite. Miner Petrol 100: 227-239

Thomas R, Davidson P (2012) The application of Raman spectroscopy in the study of fluid and melt inclusions. Z Dtsch Ges Geowiss 163: 113-126

Van Schmus WR, Brito Neves BB, Williams IS, HackSPACher PC, Fetter AH, Dantas EL, Babinski M (2003) The Seridó Group of NE Brazil, a late Neoproterozoic pre- to syn-collisional basin in West Gondwana: insights from SHRIMP U-Pb detrital zircon ages and Sm-Nd crustal residence $\left(T_{D M}\right)$ ages. Precambr Res 127: 287-327

VERNON RH (1979) Formation of sillimanite by hydrogen metasomatism (base-leaching) in some high-grade gneisses. Lithos 12: 143-152

VERNON RH (1987) Oriented growth of sillimanite in andalusite, Placitas-Juan Tabo area, New Mexico, U.S.A. Can J Earth Sci 24: 580-590

Weber SU, Grodzicki M, Lottermoser W, Redhammer GJ, Topa D, Tippelt G, Amthauer G (2007) ${ }^{57}$ Fe Mössbauer spectroscopy, X-ray single crystal diffractometry and electronic structure calculations on natural sinhalites. Phys Chem Miner 36: 259-269

WINTSCH RP (1975) Solid-fluid equilibria in the system $\mathrm{KAlSi}_{3} \mathrm{O}_{8}-\mathrm{NaAlSi}_{3} \mathrm{O}_{8}-\mathrm{AlSiO}_{5}-\mathrm{SiO}_{2}-\mathrm{H}_{2} \mathrm{O}-\mathrm{HCl}$. J Petrol 16: $57-79$

WinTsCh RP, ANDREWs MS (1988) Deformation induced growth of sillimanite: "stress" minerals revisited. J Geol 96: 143-161

ŽÁČEK V, VRÁNA S (2002) Iron-rich chrysoberyl from Kalanga Hill, Muyombe District, north-eastern Zambia. Neu Jb Miner, Mh 2002: 529-540 